\title{
Long-term monitoring of the endemic Rana latastei: suggestions for after-LIFE management
}

\author{
Luca CAnova and Alessandro BaLestrieri
}

\begin{abstract}
We monitored egg clutch numbers of a population of the endemic Italian agile frog Rana latastei in a Site of Community Interest in northern Italy (SCI IT 209000) during 1997-2017 with the aim of assessing the long-term variation in its abundance. We walked along the banks of canals and small ponds $(n=22) 1-3$ times per week between early February and mid-April each year to detect egg clutches. The relationships between the start of the breeding season, yearly egg mass counts, rate of yearly change in the number of recorded egg masses and 15 climatic and environmental variables were assessed by multiple regression. The first deposition of eggs occurred progressively later in the year throughout the study period and mean air temperature during the breeding season decreased over this period. Agile frogs showed high deposition site-fidelity. Despite large variations in the number of egg clutches detected from year to year, the population size remained stable in the long term. Peaks in the number of egg clutches occurred 2 years after the dredging of canals, carried out every 4-6 years to improve water availability, starting in 2004 as part of a LIFE Nature Project. This was the only predictor of the number of egg clutches deposited, suggesting that periodical management is needed to support the agile frog population. Our results reinforce the need for multi-year monitoring to determine both the long-term success of habitat restoration projects and the status of residual populations.
\end{abstract}

Keywords Clutch size, conservation, habitat restoration, Italian agile frog, LIFE projects, long-term monitoring, population trend, Rana latastei

\section{Introduction}

mphibian populations worldwide are declining at an A alarming rate (McCallum, 2007; Hayes et al., 2010), with $32 \%$ of amphibian species threatened; i.e. categorized as Vulnerable, Endangered or Critically Endangered on the IUCN Red List (Stuart et al., 2004). Several anthropogenic factors contribute to their decline, including habitat

Luca Canova Department of Chemistry, University of Pavia, Pavia, Italy

Alessandro Balestrieri (Corresponding author) Department of Biosciences, University of Milan, Via Celoria 26, I-20133 Milan, Italy

E-mail alebls@libero.it

Received 25 August 2017. Revision requested 3 October 2017.

Accepted 1 December 2017. First published online 18 July 2018. loss (Houlahan \& Findlay, 2003; Cushman, 2006), pollution (Bridges \& Semlitsch, 2000), disease epidemics and climate change (Kiesecker et al., 2001; Ficetola \& Maiorano, 2016). As for many other taxa (Menzel et al., 2006; Thackeray et al., 2010; Chen et al., 2011), a shift to earlier breeding as a result of global warming has been reported for several anuran species (Terhivuo, 1988; Reading, 1998; Corn, 2003; Tryjanovski et al., 2003). Shifts are stronger for anurans than those reported for trees, birds and butterflies (Parmesan, 2007), but the consequences of earlier breeding for population dynamics are still unknown.

Neither phenological shifts (Blaustein et al., 2001), nor population decline (Blaustein et al., 1994; Richter et al., 2003; Stuart et al., 2008) affect all amphibian populations. The reasons for these variations are still being debated and identifying them requires information on breeding ecology and population trends, which is often difficult to obtain, particularly for rare or declining species (Richter et al., 2003).

In amphibians clutch size (the number of egg masses deposited) is an important life history trait that varies between taxonomic groups, populations, and individuals within the same population (Wells, 2007; Cadeddu \& Castellano, 2012). At population-level, variation in clutch size depends on food availability and environmental conditions, mainly temperature (Reading, 1998), rainfall (Jensen et al., 2003) and hydroperiod (Semlitsch et al., 1996). Climatic conditions in spring may affect the length of the breeding period (Jørgensen, 1984; Reading \& Clarke, 1995), resulting in variations in clutch sizes (Morrison \& Hero, 2003).

Egg clutch counts have been widely used for monitoring amphibian populations (Crouch \& Paton, 2000; Bernini et al., 2004; Loman \& Andersson, 2007) and are considered a valid indicator of population trends (Meyer et al., 1998; Houlahan et al., 2000). Because the number of egg masses deposited can vary significantly between years, collecting data for $>20$ years may be necessary to assess the trend of an amphibian population with sufficient precision (Scherer \& Tracey, 2011).

In addition to providing descriptions of population dynamics, long-term data are needed to identify changes driven by anthropogenic stressors (Magurran et al., 2010) and the causes of declining amphibian populations (Stuart et al., 2004). Long-term data improve ecosystem models and forecasts, supporting effective management actions (Giron-Nava et al., 2017).

Despite its importance for conservation management, long-term monitoring and collection of basic data on 
fecundity and population trends are often hampered by low funding and unstable political conditions (Elzinga et al., 2001; Estrada, 2014). Only a few egg clutch time series spanning $>10$ years are available, including 22-27 years for Rana temporaria (Switzerland; Meyer et al., 1998), 16 years for Lithobates sylvaticus (New England; Raithel et al., 2011), and 10 years for Rana dalmatina (Italy; Bernini et al., 2004).

Although Palearctic amphibians are less threatened than tropical species, northern Italy is among the Eurasian areas hosting the highest number of endemic and threatened species: 14 out of $44(32 \%)$ are endemic and 14 are categorized as threatened (4 Endangered and 10 Vulnerable) on the IUCN Red List (Stuart et al., 2008; Rondinini et al., 2013). The Mediterranean region is considered a hotspot for conservation investment (Myers et al., 2000; Brooks et al., 2002).

The Italian agile frog Rana latastei is a monotypical, endemic species of northern Italy, the Swiss canton Ticino (Grossenbacher, 1997) and the Istria peninsula (Burlin \& Dolce, 1986), and also occurs locally in lowland hygrophilous woods below $500 \mathrm{~m}$ in Slovenia and Croatia (Barbieri \& Mazzotti, 2006). Females lay their eggs in February-April in single clutches (one per year), which are usually deposited within $50 \mathrm{~cm}$ of the water surface of river pools, ponds, springs and canals in wooded areas. Deposition sites are typically rich in aquatic vegetation or provide submerged branches and leaves (Barbieri \& Mazzotti, 2006). R. latastei is an explosive breeder, with most ovipositions occurring within 2-15 days, eggs hatching 10-15 days after deposition, and tadpoles completing their metamorphosis in c. 3 months (Sindaco et al., 2005). Less than 100 breeding sites are known (Grossenbacher, 1997), most populations are fragmented and genetic diversity decreases from east to west and in peripheral populations (Garner et al., 2003). The species is included in Annexes II and IV of the Habitat Directive of the European Union (EC 43/1992) and categorized as Vulnerable on the IUCN Red List. Reasons for concern are water pollution, increasing urbanization and widespread intensive agriculture, which threaten the residual humid deciduous forests of the Po-Venetian plain, one of the most densely populated areas in Italy (Lassini et al., 2007; Sindaco et al., 2009). Additional threats are invasive predatory fishes and crayfish, which have a negative impact on amphibian communities (Ficetola et al., 2012a) and may have caused the extinction of $R$. latastei from part of its range (Ficetola et al., 2012b).

Considering the Italian agile frog one of the most threatened amphibians in Europe, the Standing Committee of the Bern Convention commissioned an Action Plan for its conservation (Edgar \& Bird, 2006) and the species has been reintroduced in five protected areas of the Lombardy region in northern Italy (Scali et al., 2001; Bernini \& Razzetti, 2002). Despite the increasing interest in its conservation, until now only short-term population surveys have been carried out for this species, with the exception of a 7 -year census
(Bernini et al., 2004). The Action Plan has highlighted the need for long-term ( $>10$ years) studies (Edgar \& Bird, 2006) to account for large annual fluctuations of population size. We monitored egg clutch sizes over a 21-year period (1997-2017) in a small protected area in the Lombardy region with the aim of determining long-term variation in agile frog abundance. Because the area was the subject of a 2-year LIFE Nature Project (LIFEo3 NAT/IT/ooo112) to increase habitat suitability for amphibians and Ardeidae during 2003-2005, we also aimed to assess the Project's long-term impact on $R$. latastei.

\section{Study area}

The study area is located at the Site of Community Interest 'Riserva di Monticchie' (SCI IT 20900o; 450836 N, 093854 E). The Site covers c. 250 ha on the left bank of the River Po, of which 24.5 ha are hygrophilous forest and 225.5 ha are agricultural land. Residual forested areas consist of alluvial woods with alder Alnus glutinosa, white willow Salix alba and common ash Fraxinus excelsior, and deciduous riparian woods with oak Quercus robur and elms Ulmus spp.

$R$. latastei has been recorded in the area since the early 1980s (Ferri, 2004). In 2003-2005 the LIFE Nature Project 'Ardeides and Amphibians: habitat conservation in the Monticchie Natural Reserve' (LIFEo3 NAT/IT/ooo112) aimed to increase the cover of alluvial forests through selective cutting of allochthonous species, planting of 10,300 indigenous trees and shrubs over a 5 ha area, and restoration of water quality and availability in canals and springs by improving the existing canal network and the circulation of ground water arising from the foot of a fluvial terrace (Fig. 1). Since 2004, canals have been periodically dredged to remove sediments and improve water availability.

\section{Methods}

From 1997 to 2017 all waterbodies $(n=22)$ of the site were surveyed 1-3 times per week from early February until c. mid April (depending on rainfall and frog breeding activity) and deposited egg masses were counted. Clutches were detected by walking along the banks of canals $(n=19$, total length $=2,340 \mathrm{~m}$, mean length $=120.9 \pm \mathrm{SD} 69.9 \mathrm{~m}$; mean width $=1.74 \pm$ SD $0.54 \mathrm{~m}$ ) and small ponds $10-70 \mathrm{~cm}$ deep $(\mathrm{n}=3$, width $=3-10 \mathrm{~m})$. Surveys were usually carried out in the morning, by a main observer and a helper who recorded the main observer's count and any sightings of additional egg masses. Both observers wore polarized sunglasses to reduce the glare of the sun on the water. To help with the identification of newly-laid clutches, all egg masses were photographed and their location marked on a map of the site with landmarks such as trees and stones. 


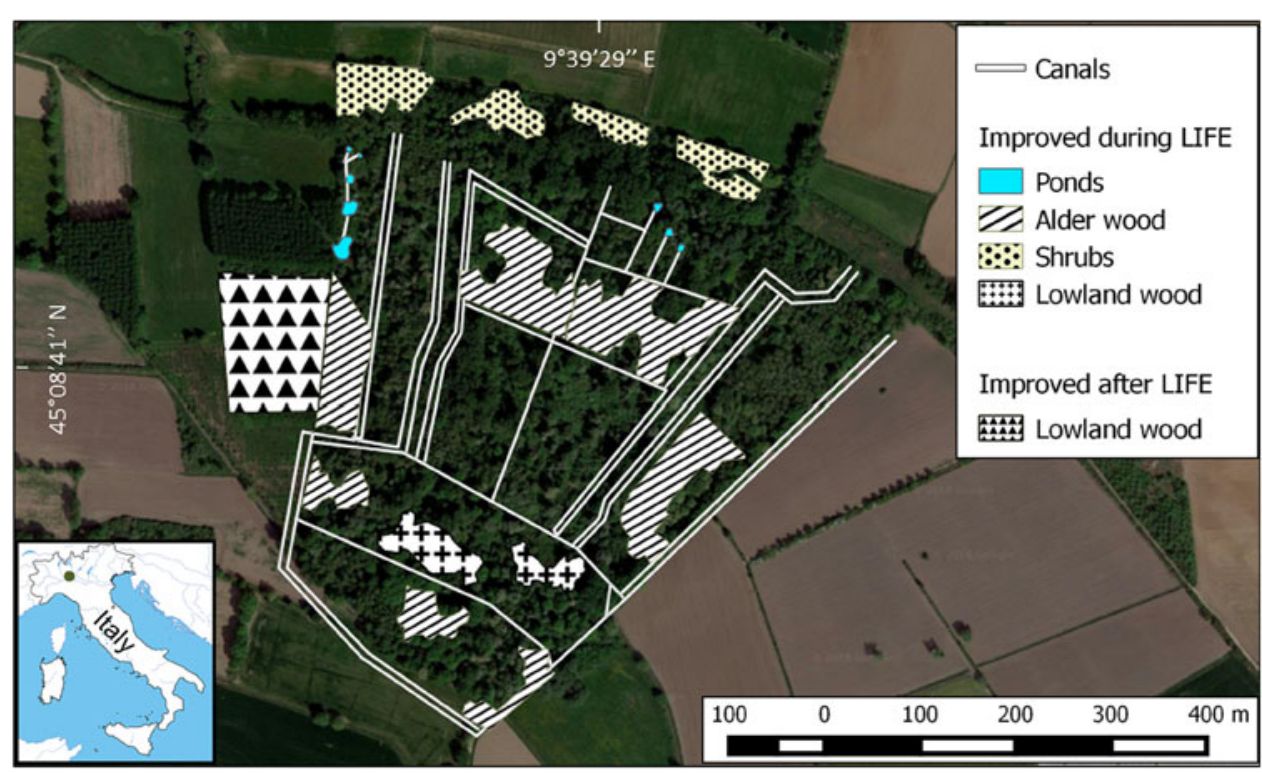

FIg. 1 Aerial view of the study area in 2017. Wooded areas that have been improved during or after the LIFE project (2003-2005) and the canal network are highlighted. The location of the study area in Italy is shown on the inset map.
Because the agile frog $R$. dalmatina, whose egg clutches are similar to those of $R$. latastei (Bernini et al., 2004), has never been recorded in the study area despite several surveys (e.g. Ferri, 1988, 2004; Canova \& Marchesi, 2007) and hydrophone recordings (G. Pavan, unpubl. data), all egg masses could be assigned unequivocally to the target species.

The rate of yearly change in egg mass number was measured using the $\Delta N$ method (Houlahan et al., 200o): $\Delta N=\log (N+1)_{t}-\log (N+1)_{t-1}$, where $N$ represents the population size (number of the egg masses) at time $t$.

The relationship between the start of the breeding season (the ordinal date when the first egg mass was recorded), yearly egg mass counts, and rate of yearly change in egg mass number and climatic and environmental variables was first explored by Spearman's correlation coefficient. The following independent variables were used: (1) year, (2) total precipitation $(\mathrm{mm})$ in February in the years when egg masses were counted, (3) total precipitation during the previous year (rainfall affects adult survival; Berven, 1990), (4-6) mean maximum temperature in January (prereproductive period), February (start of breeding activity) and February-March (overall reproductive period), (7-9) mean minimum temperature and (10-12) overall mean temperature in the same three periods, (13) air humidity in February, (14) water availability, and (15) mean water depth.

Rainfall (mm), air humidity (\%) and mean temperatures $\left({ }^{\circ} \mathrm{C}\right)$ were calculated from daily values obtained from the historical archives of the weather stations of Piacenza and Sant'Angelo Lodigiano (Regional Agency for Environmental Protection), which are c. 15 and $20 \mathrm{~km}$ from Monticchie, respectively. Water availability was expressed as the per cent length of canals with water depth $\geq 10 \mathrm{~cm}$; each year, water depth was measured at deposition sites when egg clutches were recorded.
All climatic and environmental variables that were not correlated with any of the dependent variables $(\mathrm{P}>0.05)$ were discarded from subsequent analyses. The influence of the remaining variables on reproductive activity was then analysed using multiple regression. Before the analyses, all variables were tested for normality by KolmogorovSmirnov's test. When necessary, data were transformed to achieve normality and homoscedasticity by Box-Cox's method (1964). To avoid multicollinearity, which can inflate the standard errors of the estimates of the model coefficients and produce unreliable results (Hosmer \& Lemeshow, 1989; Quinn \& Keough, 1993), correlations between the predictors were measured by Pearson's coefficient. Variables to be entered in the model were then selected to omit those clearly representing redundant information; when two variables were correlated, the one to be rejected was chosen according to the strength of its correlation with the dependent variable. The model was then fitted with the predictors in decreasing order, according to the strength of correlation between the dependent variable and each predictor, and following backward elimination of the non-significant predictors (sequential regression method).

Trends through time of climatic variables recorded in February were estimated by regression of each variable on year. Statistical analyses were run in SPSS 21.0 (IBM, Armonk, USA) and PAST 2.17c (Hammer et al., 2001).

\section{Results}

The number of egg clutches recorded in a single breeding season ranged from 12 in 2002 to 813 in 2010 (mean $=139.9 \pm$ SD 202.8; Fig. 2). Peaks in the number of eggs deposited by $R$. latastei occurred 2 years after dredging (Fig. 2). The overall trend in the rate 


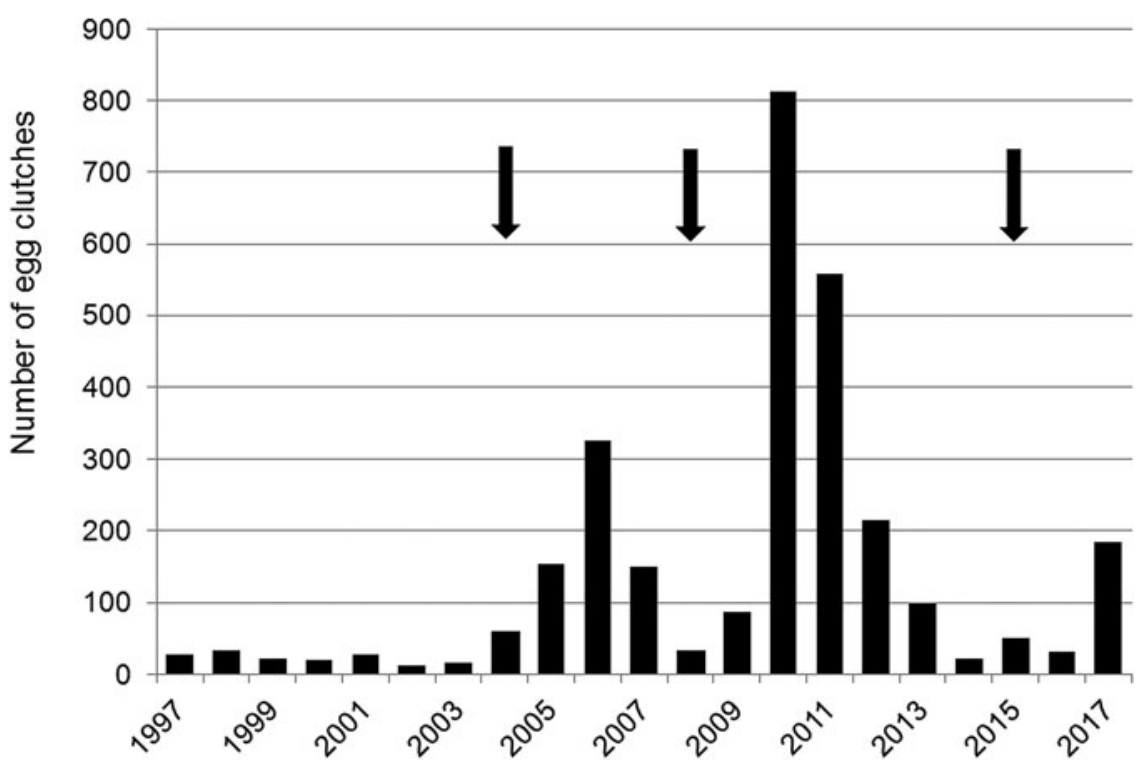

FIG. 2 Yearly variation in the number of egg clutches deposited by Rana latastei at the Site of Community Interest 'Riserva di Monticchie' in northern Italy. Arrows indicate the years when the canal network was dredged to increase water availability. of yearly change in egg mass number was slightly positive over the study period $(\Delta N=0.04 \pm$ SD 0.45 ; Fig. 3$)$.

Throughout the study period, agile frogs most frequently selected the same group of canals in the centre of the site for egg deposition, with $70 \%$ of all egg clutches deposited there. These canals were used in $68-86 \%$ of reproductive seasons, whereas 14 out of the 21 monitored canals were used $\leq 4$ times, mainly during reproductive peaks.

The number of egg clutches increased with water availability $(r=0.77, \mathrm{P}<0.001)$ and depth $(r=0.7, \mathrm{P}=0.003)$, and was inversely related to maximum air temperature in February $(r=0.56, \mathrm{P}=0.007$ ) (Fig. 4). Water availability was the only predictor included in the regression model for the number of egg clutches deposited ( $b=0.011 \pm \mathrm{SD} 0.01, \mathrm{P}<0.0001)$. When running multiple regressions with only the climatic variables, the final model included the mean maximum temperature in February $(b=-0.09 \pm \mathrm{SD} 0.03, \mathrm{P}=0.008)$.
The first egg clutch was detected at a mean of 44.2 \pm SD 4.5 days, with the ordinal date of first deposition increasing significantly throughout the study period $\left(b=2 \cdot 10^{-9} \pm \mathrm{SD}\right.$ $5.9 \cdot 10^{-10}, \mathrm{P}=0.003$; Fig. 5). The analysis of year-to-year variation in climatic variables showed that the mean daily maximum temperature in February decreased and air humidity increased (Table 1; Fig. 5). Breeding date and maximum temperature in February were inversely related, although not significantly $(r=-0.39, \mathrm{P}=0.08)$.

\section{Discussion}

Egg counts are typically incomplete and represent only a proportion of the actual female population (Campbell Grant et al., 2005). Although we did not account for detectability, we surveyed each waterbody several times per breeding season, ensuring that our count of egg masses

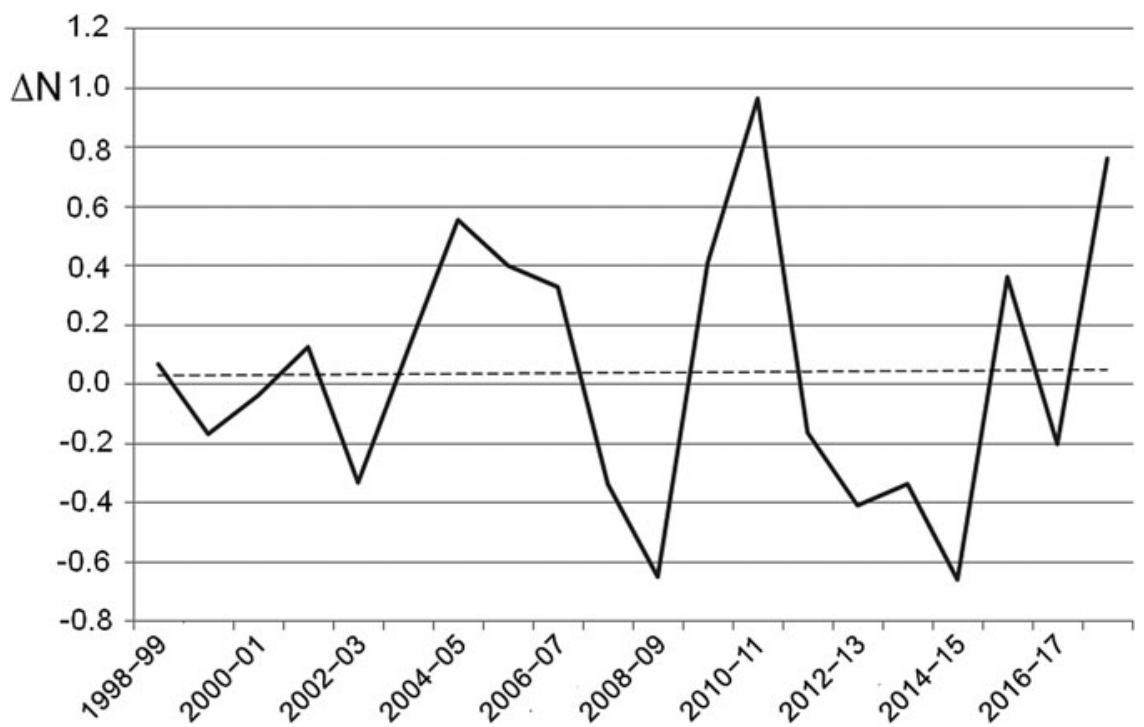

FIG. 3 Rate of yearly change $(\Delta N)$ in $R$. latastei egg clutch numbers at the Site of Community Interest 'Riserva di Monticchie' in northern Italy. The dashed line shows the slightly positive overall trend. 

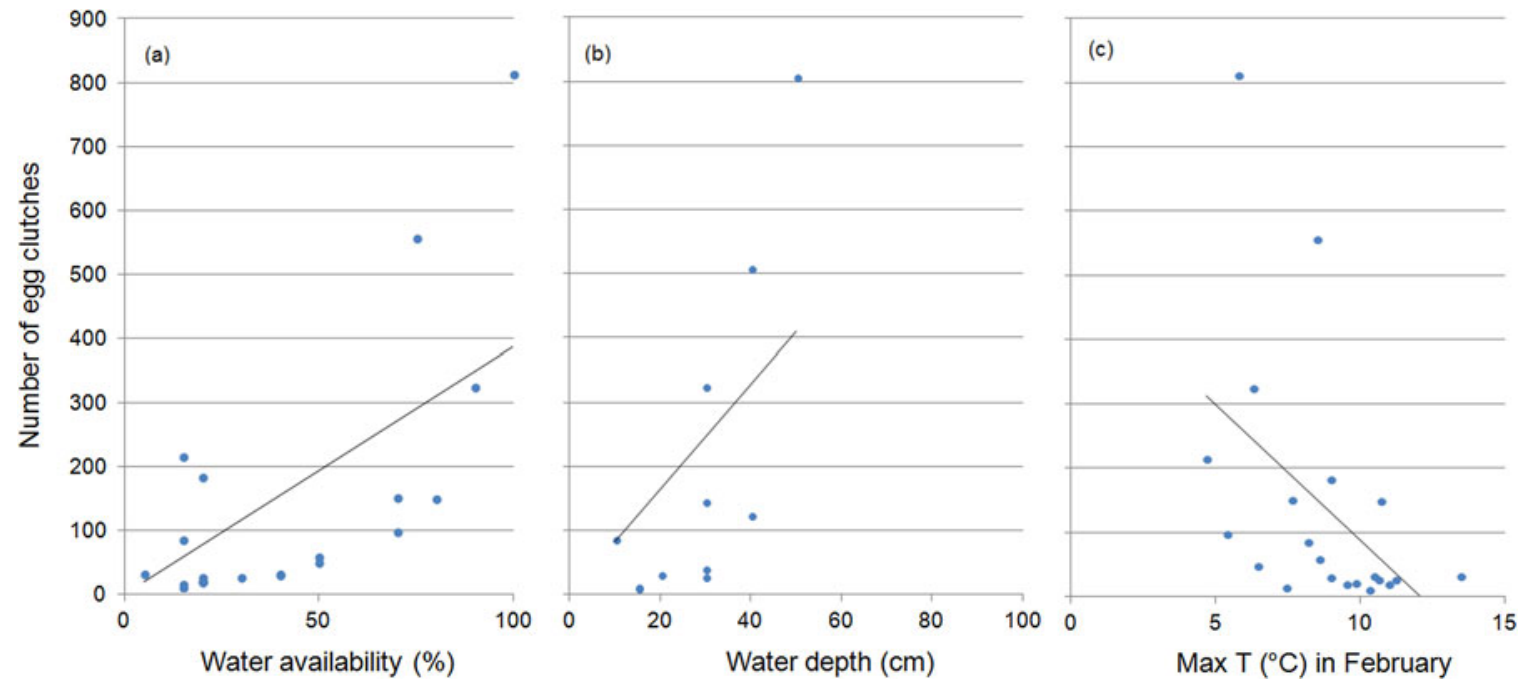

FIG. 4 The effect of (a) water availability, (b) water depth and (c) maximum water temperature on the number of egg clutches deposited by $R$. latastei in the study area during 1997-2017. Regression lines are shown for each graphic.

was as complete as possible. Because the same surveys methods were used every year, we expected inter-year comparisons to reflect fluctuations in breeding population size accurately.

Italian agile frogs were consistently found to breed in the monitored area throughout the study period. However, as reported for several other anuran species (Richter et al., 2003; Hartel, 2008; Scherer \& Tracey, 2011) the number of egg clutches deposited varied significantly between years. Despite this variation in reproductive output, monitoring over 2 decades revealed no clear trend, suggesting an overall stable breeding population.

This result contrasts with the conclusions of the final report of the LIFE Nature Project (Marzatico, 2005) carried out in 2003-2005, which stated 'a large increase [...] in the amount of eggs deposited'. Although the sudden increase in clutch number recorded during the intervention supported the actions undertaken by project managers, our results reinforce the need for multi-year monitoring to determine the long-term success of species-specific habitat restoration projects (Silva et al., 2014). The risk of drawing erroneous conclusions about population trends from the analysis of short-term data has also been highlighted in previous analyses of 25-year long time-series (Meyer et al., 1998; Pechmann et al., 1991).

Variation in clutch numbers depends on weather conditions such as daily fluctuations in temperature and humidity during the breeding season, rainfall in the previous seasons, habitat changes and demographic patterns (i.e. the survival rate of adults in the pre-reproductive period) (Berven, 1990; Reading \& Clarke, 1995; Harper \& Semlitsch, 2007; Wells, 2007). In the study area, climatic conditions in both the prereproductive and breeding periods played a negligible role in determining year-to-year variation in the number of egg clutches deposited. The negative effect of maximum air temperature in February on the number of egg clutches deposited is difficult to explain, although frogs breeding in closed canopy ponds may be less tolerant of high temperatures than those from open areas (Skelly \& Freidenburg, 2000). Because males call underwater (Farronato et al., 2000) and water temperature remained constant, variations in air temperature might not affect breeding activity. Rainfall, which has been shown to affect breeding population size in other amphibians (Semlitsch et al., 1996), did not seem to affect population fluctuations of $R$. latastei. Similar results have been found for three populations of $R$. temporaria (Meyer et al., 1998).

For anurans that deposit their eggs in standing water ( $80 \%$ of anuran families; Duellman \& Trueb, 1986), water availability is a major determinant of both distribution (Banks et al., 1994; Rodriguez et al., 2005) and reproductive success (Rowe \& Dunson, 1993, 1995). The relationship between clutch size and water availability (per cent length and depth of active canals) recorded in our study confirms the importance of the availability of suitable oviposition sites during the breeding period. The importance of water availability was also indicated by the clutch size peaks following dredging actions, which started in 2004 during the LIFE project and aimed to improve water circulation in the canal network. The 2-year delay between dredging and clutch size peaks may be explained by the time required for the renewal of aquatic vegetation and deposition of leaf litter and wood debris, which agile frogs require for breeding (Barbieri \& Bernini, 2004). Another factor may have been that dredging was carried out in November, potentially disturbing hibernating frogs. Canals used regularly for oviposition were located in the inner, less disturbed and more forested part of the study area. These canals showed lower variation in water availability throughout the study period compared to peripheral water bodies and have 

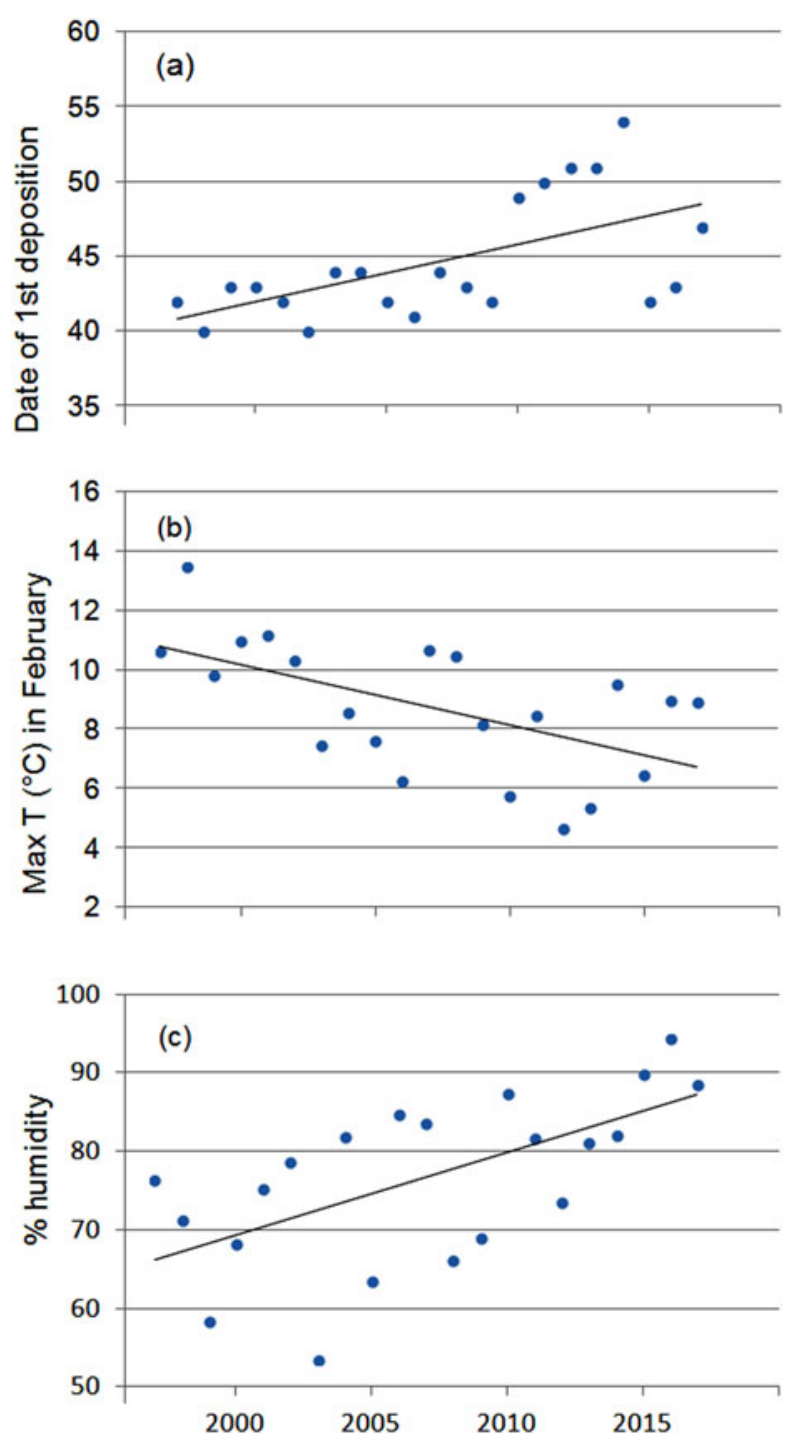

FIG. 5 Variation in (a) date of first deposition, (b) maximum air temperature and (c) humidity in February during 1997-2017. Regression lines are shown for each graphic.

been used by frogs since the 1980s (Ferri \& Agapito Ludovici, 2002), suggesting high site-fidelity. The larger number of canals used during reproductive peaks reflects the higher water availability following dredging and suggests that in dry springs intraspecific competition for oviposition sites may be more intense.

In temperate regions the beginning of breeding activity in explosive-breeding anurans is determined by rising temperatures at the end of winter (Wells, 2007; Sofianidou \& Kyriakopoulou-Sklavounou, 1983) and mean air temperature in February can affect the breeding dates of Rana spp. (Terhivuo, 1988; Hartel, 2008). In the 20-year period of monitoring, a period long enough to detect shifts in the onset of breeding caused by climate change (Reading, 1998; Beebee, 1995; Forchhammer et al., 1998), agile frogs tended to breed progressively later. This finding, which contrasts
TABLE 1 Tests for potential trends in climatic variables at Piacenza and Sant'Angelo Lodigiano in February 1997-2017, with mean values and coefficients $(b)$ and their standard errors (SE) from regressions of the variables against year. Significant trends $(t$-tests $\mathrm{P}<0.01)$ are shown in italics.

\begin{tabular}{lrrll}
\hline & Mean & \multicolumn{1}{l}{$B$} & SE & P \\
\hline Mean temperature $\left({ }^{\circ} \mathrm{C}\right)$ & 4.77 & -0.700 & 0.703 & 0.332 \\
Minimum temperature $\left({ }^{\circ} \mathrm{C}\right)$ & -0.04 & 0.489 & 0.607 & 0.430 \\
Maximum temperature $\left({ }^{\circ} \mathrm{C}\right)$ & 8.76 & -1.574 & 0.527 & 0.008 \\
Dew point $\left({ }^{\circ} \mathrm{C}\right)$ & 1.37 & 1.057 & 0.423 & 0.022 \\
Air humidity $(\%)$ & 76.73 & 0.354 & 0.105 & 0.003 \\
Wind speed $(\mathrm{km} / \mathrm{h})$ & 6.69 & 1.279 & 0.677 & 0.074 \\
Rainfall $(\mathrm{mm})$ & 63.73 & 0.047 & 0.023 & 0.054 \\
\hline
\end{tabular}

with the global trend, corresponds with the recorded decrease in the daily maximum temperatures in February, although mean temperatures did not vary accordingly. Other studies have also found that some anuran species do not tend to breed earlier or even show a tendency to breed later (Blaustein et al., 2001; Gibbs \& Breisch, 2001), probably as a consequence of local variation in climatic conditions.

Yearly monitoring allowed us to record the actual trend of the local agile frog population, relating large fluctuations in clutch size to water availability and management actions and assessing the long-term success of the LIFE Nature Project. Although pre-metamorphic survival is mainly determined by density dependent factors (Berven, 1990), anecdotal evidence suggests that water availability also may be important for agile frog reproductive success during the developmental period. During 1980-2000, most canals occasionally dried up before tadpoles underwent metamorphosis (Ferri, 2004), threatening tadpole survival and their recruitment into the breeding population in subsequent years. Given that rainfall increased only slightly during the study period, drying up was probably caused by either the occlusion of groundwater springs by sediments or water usage for agricultural purposes.

The periodical dredging (every 4 years) of the existing canal network is an important management action to ensure the availability of suitable breeding sites and support the conservation of this agile frog population. The results of our long-term monitoring suggest that in small wooded areas in an agricultural landscape, water availability can be highly variable because of its exploitation for watering surrounding crops, and can become a limiting factor for amphibians. In such cases, we recommend the following management measures: (1) dredging should be carried out regularly to prevent the silting up of canals and ensure a water depth suitable for oviposition and tadpole development (40-60 cm), (2) dredging activities should be carried out at the end of summer, before the species enters hibernation, and (3) long-term monitoring ( $>10$ years) of the size of the targeted population beginning at the start 
of a project is required for a full assessment of the success of conservation interventions. Site-fidelity implies that habitat restoration and reintroduction or reinforcing plans need to take into account the historical distribution of the species in the intervention area, and that many years may pass before agile frogs colonize a new area permanently.

Efforts to recreate aquatic and terrestrial habitats to support the long-term viability of agile frog populations have been limited to date (Edgar \& Bird, 2006). Since 2011, the reserve authorities have managed to increase water availability and stabilize water levels at the study site. The first intervention was the construction of an artificial pond, connected to the water table, to which egg clutches can be moved when canals dry up. Authorities are currently planning to construct shallow ponds and marshy areas, covering c. 4 ha, to provide further suitable deposition sites. An additional step may be the creation of a buffer zone to avoid pollution of the inner area during chemical treatment of neighbouring croplands. Our results have also been considered for preparing a Regional Action Plan for the conservation of threatened aquatic species.

Acknowledgements We thank the administration of Monticchie Natural Reserve and Assessorato Ambiente, Regione Lombardia for funding [GC-32-17042009; GC-99-28122011], permissions and logistic support, P. Mazzoleni for permission to visit his farms, and A. Mascherpa, A. Cremonesi, A. Lucchini, S. Ghidotti and S. Uccellini for their help with fieldwork. G. Pavan recorded and analysed male calls by hydrophone and S.J. Lovejoy provided language editing.

Author contributions Research conception and clutch size monitoring: LC; data analysis: $\mathrm{AB}$; writing of the manuscript: $\mathrm{LC}$ and $\mathrm{AB}$.

Ethical standards The research was non-intrusive and had the necessary approval and permits from the administrations of Monticchie Natural Reserve and Lombardy Region.

Conflicts of interest None.

\section{References}

Banks, B., Beebee, T.J.C. \& Cooke, A.S. (1994) Conservation of the natterjack toad Bufo calamita in Britain over the period 1970-1990 in relation to site protection and other factors. Biological Conservation, 67, 111-118.

Barbieri, F. \& Bernini, F. (2004) Distribution and status of Rana latastei in Italy (Amphibia, Ranidae). Italian Journal of Zoology, 71, Suppl. 1, 91-94.

Barbieri, F. \& Mazzoti, S. (2006) Rana latastei. In Atlante degli Anfibi e dei Rettili d'Italia (Atlas of Italian Amphibians and Reptiles) (eds R. Sindaco, G. Doria, E. Razzetti \& F. Bernini), pp. 362-367. Societas Herpetologica Italica, Edizioni Polistampa, Firenze, Italy.

Beebee, T.J.C. (1995) Amphibian breeding and climate. Nature, 374, 219-20.

Bernini, F. \& Razzetti, E. (2002) Reintroduzione di Rana latastei nella Riserva Naturale Bosco 'G.Negri' (Pavia). In $4^{\circ}$ Congresso
Nazionale della Societas Herpetologica Italica (eds O. Picariello, G. Odierna, F.M. Guarino \& D. Capolongo), pp. 51-52. Università degli Studi di Napoli Federico II, Napoli, Italy.

Bernini, F., Gentilli, A., Merli, E. \& Razzetti, E. (2004) Rana dalmatina and R. latastei: Habitat selection, fluctuation in egg clutch deposition and response to exceptional floods in northern Italy. Italian Journal of Zoology, 71, Suppl. 2, 147-149.

BERVEN, K.A. (1990) Factors affecting population fluctuations in larval and adult stages of the wood frog (Rana sylvatica). Ecology, 71, 15991608 .

Blaustein, A.R., Wake, D.B. \& Sousa, W.P. (1994) Amphibian declines: judging stability, persistence, and susceptibility of populations to local and global extinctions. Conservation Biology, 8, 60-71.

Blaustein, A.R., Belden, L.K., Olson, D.H., Green, D.M., Root, T. L. \& Kiesecker, J.M. (2001) Amphibian breeding and climate change. Conservation Biology, 15, 1804-1809.

Box, G.E.P. \& Cox, D.R. (1964) An analysis of transformations. Journal of the Royal Statistical Society Series B, 26, 211-252.

Bridges, C.M. \& Semlitsch, R.D. (2000) Variation in pesticide tolerance of tadpoles among and within species of Ranidae and patterns of amphibian decline. Conservation Biology, 14, 1490-1499.

Brooks, T.M., Mittermeier, R.A., Mittermeier, C.G., DA Fonseca, G.A.B., Rylands, A.B., Konstant, W.R. et al. (2002) Habitat loss and extinction in the hotspots of biodiversity. Conservation Biology, 16, 909-923.

Burlin, M. \& Dolce, S. (1986) Osservazioni faunistiche sull'erpetofauna dell'Istria. Atti Museo Civico di Storia Naturale di Trieste, 39, 65-85.

Cadeddu, G. \& Castellano, S. (2012) Factors affecting variation in the reproductive investment of female treefrogs (Hyla intermedia). Zoology, 115, 372-378.

Campbell Grant, E.H., Jung, R.E., Nichols, J.D. \& Hines, J.E. (2005) Double-observer approach to estimating egg mass abundance of pool-breeding Amphibians. Wetlands Ecology and Management, 13, 305-320.

Canova, L. \& Marchesi, M. (2007) Amphibian and reptile communities in eleven Sites of Community Importance (SCI): relations between SCI area, heterogeneity and richness. Acta Herpetologica, 2, 87-96.

Chen, I.-C., Hill, J.K., Ohlemüller, R., Roy, D.B. \& Thomas, C.D. (2011) Rapid range shifts of species associated with high levels of climate warming. Science, 333, 1024-1026.

Corn, P.S. (2003) Amphibian breeding and climate change: the importance of snow in the mountains. Conservation Biology, 17, $622-625$.

Crouch, W.B. \& Paton, P.W.C. (2000) Using egg mass counts to monitor wood frog populations. Wildlife Society Bulletin, 28, 895-901.

Cushman, S.A. (2006) Effects of habitat loss and fragmentation on amphibians: a review and prospectus. Biological Conservation, 128, 231-240.

Duellman, W.E. \& Trueb, L. (1986) Biology of Amphibians. John Hopkins University Press, Baltimore, USA.

Edgar, P. \& Bird, D.R. (2006) Action Plan for the Conservation of the Italian Agile Frog (Rana latastei) in Europe. Council of Europe, Strasbourg, France. Http://www.amphibians.org/wp-content/ uploads/2013/o8/AP_conservation-Rana-latastei-in-Europe.pdf [accessed 20 March 2018].

Elzinga, C.L., SAlzer, D.W., Willoughby, J.W. \& Gibbs, J.P. (2001) Monitoring Plant and Animal Populations. Wiley-Blackwell, Hoboken, USA

Estrada, J. (2014) Finding correlations among successful reintroduction programs: an analysis and review of current and past mistakes. MSc practicum submission, University of Michigan, Ann Arbor, USA 
Farronato, I., Pesente, M., Fracasso, G. \& Carlotto, L. (2000) Osservazioni sulle manifestazioni sonore di Rana latastei Boulenger, 1879. In Atti $3^{\circ}$ Convegno Faunisti Veneti (eds M. Bon \& F. Scarton), pp. 32-36. Museo Civico di Storia Naturale di Venezia, Venezia, Italy.

Ferri, V. (1988) Anfibi e rettili della Riserva Naturale 'Monticchie': problematiche gestionali. Technical report, WWF Session 'Basso Lodigiano', Milan, Italy.

FERri, V. (2004) Aspetti di ecologia riproduttiva di una popolazione di Rana latastei. In $V^{\circ}$ Congresso Societas Herpetologica Italiana, Calci di Pisa, October 2004 (ed. M.A.L. Zuffi), p. 61. Università di Pisa, Pisa, Italy.

Ferri, V. \& Agapito Ludovici, A. (2002) Monitoraggio delle popolazioni di Rana latastei di due riserve lombarde. In Atti $3^{\circ}$ Convegno Salvaguardia Anfibi, Lugano (ed. V. Ferri), pp. 63-70. Penne, Italy.

Ficetola, G.F. \& Maiorano, L. (2016) Contrasting effects of temperature and precipitation change on amphibian phenology, abundance and performance. Oecologia, 181, 683-693.

Ficetola, G.F., Siesa, M.E., De Bernardi, F. \& Padoa-Schioppa, E. (2012a) Complex impact of an invasive crayfish on freshwater food webs. Biodiversity and Conservation, 21, 2641-2651.

Ficetola, G.F., Siesa, M.E., Padoa-Schioppa, E. \& De Bernardi, F. (2012b) Wetland features, amphibian communities and distribution of the alien crayfish, Procambarus clarkii. Alytes, 29, 75-87.

Forchhammer, M.C., Post, E. \& Stenseth, N.C. (1998) Breeding phenology and climate. Nature, 391, 29-30.

Garner, T.W.J., Angelone, S. \& Pearman, P.B. (2003) Genetic depletion in Swiss populations of Rana latastei: conservation implications. Biological Conservation, 114, 371-376.

GibBs, J.P. \& BREISCH, A.R. (2001) Climate warming and calling phenology of frogs near Ithaca, New York, 1900-1999. Conservation Biology, 15, 1175-78.

Giron-Nava, A., James, C.C., Johnson, A.F., Dannecker, D., Kolody, B., Lee, A. et al. (2017) Quantitative argument for long-term ecological monitoring. Marine Ecology Progress Series, $572,269-274$.

Grossenbacher, K. (1997) Rana latastei. In Atlas of the Amphibians and Reptiles in Europe (ed. J.P. Gasc), pp. 146-147. Societas Herpetologica Europaea \& Museum National d'Histoire Naturelle, Paris, France.

Hammer, Ø., Harper, D.A.T. \& Ryan, P.D. (2001) PAST: paleontological statistics software package for education and data analysis. Palaeontologia Electronica, 4, 1-9.

Harper, E.B. \& Semlitsch, R.D. (2007) Density dependence in the terrestrial life history stage of two anurans. Oecologia, 153, 879-889.

HarTel, T. (2008) Weather conditions, breeding date and population fluctuation in Rana dalmatina from central Romania. The Herpetological Journal, 18, 40-44.

Hayes, T.B., Falso, P., Gallipeau, S. \& Stice, M. (2010) The cause of global amphibian declines: a developmental endocrinologist's perspective. Journal of Experimental Biology, 213, 921-933.

Hosmer, D.W. \& Lemeshow, S. (1989) Applied Logistic Regression. Wiley, New York, USA.

Houlahan, J.E. \& Findlay, C.S. (2003) The effects of adjacent land use on wetland amphibian species richness and community composition. Canadian Journal of Fisheries and Aquatic Sciences, 60, 1078-1094.

Houlahan, J.E., Findlay, C.S., Schmidt, B.R., Meyer, A.H. \& Kuzmin, S.L. (2000) Quantitative evidence for global amphibian population declines. Nature, 404, 752-755.
Jensen, J.B., Bayley, M.A., Blankenship, E.L. \& Camp, C.D. (2003) The relationship between breeding by the gopher frog Rana capito (Amphibia: Ranidae) and rainfall. American Midland Naturalist, 150, 185-190.

JørGensen, C.B. (1984) Ovarian functional patterns in Baltic and Mediterranean populations of a temperate zone anuran, the toad Bufo viridis. Oikos, 43, 309-321.

Kiesecker, J.M., Blaustein, A.R. \& Belden, L.K. (2001) Complex causes of amphibian population declines. Nature, 410, 681-684.

Lassini, P., Monzani, F. \& Pileri, P. (2007) A green vision for the renewal of the Lombardy landscape. In Europe's Living Landscapes. Essays on Exploring our Identity in the Countryside (eds B. Pedroli, A. Van Doorn, G. De Blust, M.-L. Paracchini, D. Wascher \& F. Bunce), pp. 83-100. KNNV Publishing, Zeist, The Netherlands.

Loman, J. \& Andersson, G. (2007) Monitoring brown frogs Rana arvalis and Rana temporaria in south Swedish ponds 1989-2005. Mixed trends in different habitats. Biological Conservation, 135, 46-56.

Magurran, A.E., Baillie, S.R., Buckland, S.T., Dick, J.M., Elston, D.A., Scott, E.M. et al. (2010) Long-term datasets in biodiversity research and monitoring: assessing change in ecological communities through time. Trends in Ecology \& Evolution 25, 574-582.

Marzatico, C. (2005) LIFE Natura IT 03/ooo112, Final Divulgative Report. Http://ec.europa.eu/environment/life/project/Projects/ index.cfm?fuseaction=home.showFile\&rep=file\&fil=LIFEo3_NAT_ IT_ooo112_LAYMAN.pdf [accessed 10 February 2018].

McCallum, M.L. (2007) Amphibian decline or extinction? Current declines dwarf background extinction rate. Journal of Herpetology, 41, 483-491.

Menzel, A., Sparks, T.H., Estrella, N., Koch, E., Aasa, A., Ahas, R. et al. (2006) European phenological response to climate change matches the warming pattern. Global Change Biology, 12, 1969-1976.

Meyer, A.H., Schmidt, B.R. \& Grossenbacher, K. (1998) Analysis of three amphibian populations with quarter-century long time-series. Proceedings of the Royal Society B, 265, 523-528.

Morrison, C. \& Hero, J.-M. (2003) Geographic variation in life-history characteristics of amphibians: a review. Journal of Animal Ecology, 72, 270-279.

Myers, N., Mittermeier, R.A., Mittermeier, C.G., Da Fonseca, G.A.B. \& KENT, J. (2000) Biodiversity hotspots for conservation priorities. Nature, 403, 853-858.

PARMESAN, C. (2007) Influences of species, latitudes and methodologies on estimates of phenological response to global warming. Global Change Biology, 13, 1860-1872.

Pechmann, J.H.K., Scott, D.E., Semlitsch, R.D., Caldwell, J.P. VitT, L.J. \& Gibвons, J.W. (1991) Declining amphibian populations: the problem of separating human impacts from natural fluctuations. Science, 253, 892-895.

Quinn, G.P. \& Keough, M.J. (1993) Potential effect of enclosure size on field experiments with herbivorous intertidal gastropods. Marine Ecology Progress Series, 98, 199-201.

Raithel, C.J., Paton, P.W.C., Pooler, P.S. \& Golet, F.C. (2011) Assessing long-term population trends of wood frogs using egg-mass counts. Journal of Herpetology, 45, 23-27.

READING, C.J. (1998) The effect of winter temperatures on the timing of breeding activity in the common toad Bufo bufo. Oecologia, 117, 469-475.

Reading, C.J. \& Clarke, R.T. (1995) The effects of density, rainfall and environmental temperature on body condition and fecundity in the common toad, Bufo bufo. Oecologia, 102, 453-459.

Richter, S.C., Young, J.E., Johnson, G.N. \& Seigel, R.A. (2003) Stochastic variation in reproductive success of a rare frog, Rana 
sevosa: implications for conservation and for monitoring amphibian populations. Biological Conservation, 11, 171-177.

Rodriguez, M.A., Belmontes, J.A. \& Hawkins, B.A. (2005) Energy, water and large-scale patterns of reptile and amphibian species richness in Europe. Acta Oecologica, 28, 65-70.

Rondinini, C., Battistoni, A., Peronace, V. \& Teofili, C. (2013) Lista Rossa IUCN dei Vertebrati Italiani. Comitato Italiano IUCN e Ministero dell'Ambiente e della Tutela del Territorio e del Mare, Roma, Italy. Http://www.iucn.it/pdf/Comitato_IUCN_Lista_Rossa_ dei_vertebrati_italiani.pdf [accessed 20 March 2018].

Rowe, C.L. \& Dunson, W.A. (1993) Relationships among abiotic parameters and breeding effort by three amphibians in temporary wetlands of central Pennsylvania. Wetlands, 13, 237-246.

Rowe, C.L. \& Dunson, W.A. (1995) Impacts of hydroperiod on growth and survival of larval amphibians in temporary ponds of Central Pennsylvania, USA. Oecologia, 102, 397-403.

Scali, S., Gentilli, A., Barbieri, F., Bernini, F. \& Vercesi, A. (2001) Un progetto integrato per la conservazione degli anfibi in Lombardia. Pianura, 13, 121-123.

Scherer, R.D. \& Tracey, J.A. (2011) A power analysis for the use of counts of egg masses to monitor wood frog (Lithobates sylvaticus) populations. Herpetological Conservation and Biology, 6, 81-90.

Semlitsch, R.D., Sсотt, D.E., Pechmann, J.H.K. \& Gibbons, J.W. (1996) Structure and dynamics of an amphibian community. Evidence from a 16-year study of a natural pond. In Long-term Studies of Vertebrate Communities (eds M.L. Cody \& J.

A. Smallwood), pp. 217-248. Academic Press, San Diego, USA.

Silva, J.P., Houston, J., Toland, J., Jones, W., Eldridge, J., Thorpe, E. et al. (2014) Long-term Impact and Sustainability of LIFE Nature. European Commission, Luxembourg. Http://ec. europa.eu/environment/life/publications/lifepublications/lifefocus/ documents/lifeafterlife.pdf [accessed 20 March 2018].

Sindaco, R., Doria, G., Razzetti, E. \& Bernini, F. (2005) Atlante Degli Anfibi e dei Rettili d'Italia/Atlas of Italian Amphibians and
Reptiles. Societas Herpetologica Italica, Edizioni Polistampa, Firenze, Italy.

Sindaco, R., Romano, A., Andreone, F., Garner, T., Schmidt, B., Corti, C. \& Vogrin, M. (2009) Rana latastei. The IUCN Red List of Threatened Species. Http://dx.doi.org/10.2305/IUCN.UK.2009. RLTS.T19156A8845034.en [accessed 25 May 2018].

Skelly, D.K. \& FreidenburG, L.K. (200o) Effects of beaver on the thermal biology of an amphibian. Ecology Letters, 3, 483-486.

Sofianidou, T.S. \& Kyriakopoulou-Sklavounou, P. (1983). Studies on the biology of the frog Rana dalmatina BONAPARTE during the breeding season in Greece (Amphibia: Anura:Ranidae). Amphibia-Reptilia, 4, 125-136.

Stuart, S.N., Chanson, J.S., Cox, N.A., Young, B.E., Rodrigues, A.S.L., Fischman, D.L. \& Waller, R.W. (2004) Status and trends of amphibian declines and extinctions worldwide. Science, 306, 1783-1786.

Stuart, S.N., Hoffmann, M., Chanson, J.S., Cox, N.A., Berridge, R.J., Ramani, P. \& Young, B.E. (eds) (2008). Threatened Amphibians of the World. Lynx Edicions, Barcelona, Spain; IUCN, Gland, Switzerland; and Conservation International, Arlington, USA.

Terhivuo, J. (1988) Phenology of spawning for the Common Frog (Rana temporaria L.) in Finland from 1846 to 1986. Annales Zoologici Fennici, 25, 165-175.

Thackeray, S.J., Sparks, T.H., Frederiksen, M., Burthe, S., BACON, P.J., BELL, J.R. et al. (2010) Trophic level asynchrony in rates of phenological change for marine, freshwater and terrestrial environments. Global Change Biology, 16, 3304-3313.

Tryjanovski, I.P., Rybacki, M. \& Sparks, T. (2003) Changes in the first spawning dates of common frogs and toads in western Poland in 1978-2002. Annales Zoologici Fennici, 40, 459-464.

Wells, K.D. (2007) The Ecology and Behavior of Amphibians. University of Chicago Press, Chicago, USA. 